\title{
THE TORAJAN HOMELAND
}

If you want to understand how Tana Toraja came into being, as both a place and a social space, you need to realize that it is as much about the role of kinship systems and houses as it is about politics. I have divided this chapter into three sections that correspond to the periods in which the rules that shape the historical socio-political process were most radically different: (1) the pre-colonial period; (2) the colonial period; (3) and the post-colonial period.

The first part describes the Torajan social and political space as it existed before the highlands were invaded by the Dutch military at the beginning of the twentieth century. I pay special attention to Torajan kinship, the role and place of houses within this system, and existing forms of power and authority. Such a depiction of pre-colonial Torajan society is needed to better understand contemporary social organization and also to critically examine the continuities and changes between the past and more recent forms of authority and territory. The social and political domains are not dealt with separately because they are only detached from each other in an abstract sense; in reality the two are not independent and have never been completely separate.

Since the Dutch occupied the area in 1906, the highlands of Tana Toraja have seen a long process of power wielding and yielding over territories and government. In the second and third parts, I will elaborate on the general lines and details of history, and also on the system dynamics of the various transitional periods and the local processes that impacted on the socio-political situation in contemporary Tana Toraja. By putting the recent, seemingly 'revolutionary', tendency for local decentralization and autonomy into such a perspective, it becomes possible to obtain a thorough understanding of how the socio-political environment changed after the Indonesian decentralization laws of 1999 were introduced in Tana Toraja. Consequently, the extensive description of the social and political history of Tana Toraja in these two parts focuses on the transitional periods and local processes that had major impacts on the socio-political situation in Tana Toraja. Given that these local transitions did not occur in a vacuum, but are interrelated to power and policy changes on a national and regional level, they are presented in such a context.

(C) EDWIN DE JONG, 2013 | DOI 10.1163/9789004252479_005

This is an open access chapter distributed under the terms of the CC-BY-NC-ND License. 


\section{Early Sa'dan Toraja Society: Disunity and Diversity}

The Indonesian island of Sulawesi is marked by a variety of agroecological landscapes, which is matched by the great ethnic, cultural and religious diversity of its people. The various groups inhabiting the highlands of south and central Sulawesi are generally labelled 'Toraja'. The name 'Toraja' was originally a Buginese term used to refer to the 'people from above' or 'highlanders' in contrast to the coastal people from 'below' (Nooy-Palm 1976, 1979a). At the end of the nineteenth century, the Dutch Protestant missionaries Kruijt (also a major ethnographer of the time) and Adriani (also a linguist) adopted the term 'Toraja' to classify the ethnically and linguistically diverse mountain people who inhabited the central and southern highlands of Sulawesi (Schrauwers 1998). Kruijt drew a sharp line between the Islamic lowlanders and 'animistic' highlanders-who he considered could still be converted to Christianity—and named the latter 'Toraja' (Adriani and Kruijt 1914; Kruijt 1938). Others question Kruijt's demarcation and suggest that the religious and political agenda of the mission prevailed over ethnological and linguistic reality (see, for example, Kaudern 1925; Schrauwers 1995). Kruijt subdivided the Toraja 'ethnic' group into three smaller ones: East, West, and South Toraja (see Map 4.1). Adriani preferred to use the term 'Sa'dan' to refer to the south Torajans; the term originated from the name of the river that flows through this region. Partly inspired by these divisions, Dutch officials drew neat administrative boundaries around the valleys of the Sa'dan river and its branches at the beginning of the twentieth century. In so doing, they laid the administrative foundations for the contemporary regency of Tana Toraja-the 'common place of origin' of the Torajans discussed in this study and the focus area of this chapter.

\section{A Society of Houses}

By including most of the ingredients put forward by Lévi-Strauss (1983, 1987), it can be concluded that pre-colonial Torajan society was a good example of a house society. According to colonial reports and recent literature, the present area of Tana Toraja once consisted of a number of areas of various sizes that would sometimes unite under external pressure (against the threat of war) but usually led largely independent existences and even fought against each other (Nooy-Palm 1979a:58). Before the area came under Dutch control in 1905 it had never been a unified entity. ${ }^{1}$

${ }^{1}$ Kis-Jovak et al. 1988. In 1683, Sa'dan communities united against the occupying troops of Bone's Aru Palaka and his vassals but after this defensive act, remembered as 


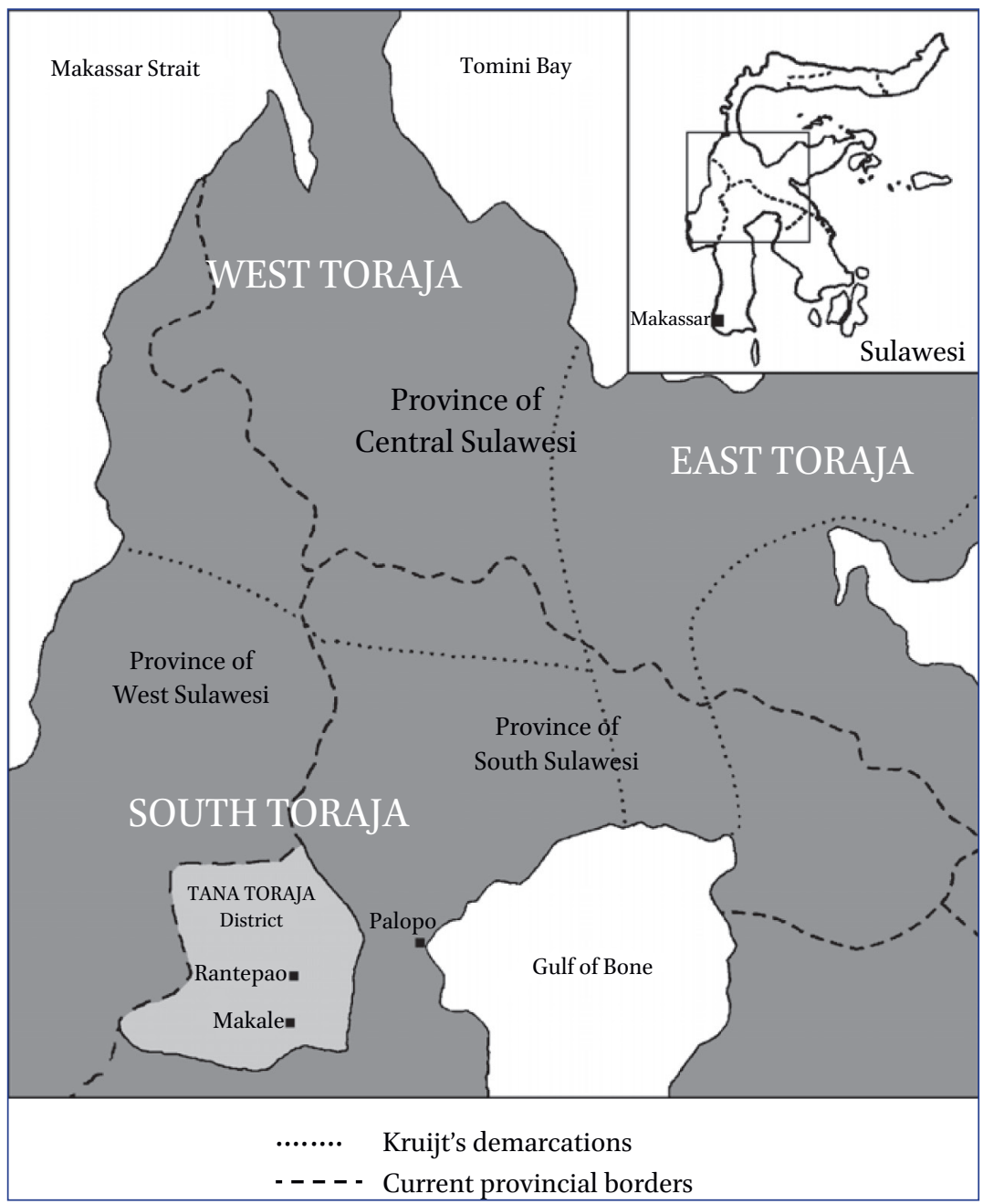

Map 4.1. Kruijt's three-way division of the highlands and the modern district of Tana Toraja.

Source: Map by Edwin de Jong.

Sa'dan Toraja consisted of complex networks of small-scale, localized kin alliances, linked through agricultural, social and ritual activities. These kinship systems are cognatic in the sense that 'descent is traced equally from both mother and father, and all children of both sexes have equal

'tulak buntunna Bone', the Sa'dan alliance dissolved (Adatstaatsrecht Loewoe, 1947, p. 41, in: KITLV, D H 907). Although this was the only occasion on which Sa'dan communities united, it is still used as a motive for Sa'dan Toraja solidarity against other ethnic groups in the region. 
rights of inheritance' (Waterson 1991:163). It follows that the smallest single entity is a set of siblings that form a kindred centre. Like most of the peoples of Western Indonesia, this set of allies, or mini-grouping in Errington's words (1989:215), is often compared to the stems of a bamboo plant which have a common mycelium, often hidden from view (see Chapter 2). The larger family group that emerges from multiplication and expansion is literally called a bamboo clump, or rapu tallang, by Torajans (Waterson 1995:197, 2009:192).

Torajan kinship is centred on the family houses (tongkonan) from which they descend. These tongkonan are regarded as 'origin sites' because they were established by the ancestors of a specific group. If a kin group became too large, it split and the severed branch built itself a new tongkonan. The descendants that set out however remained conscious of their origin and retained ceremonial responsibilities to the mother tongkonan (Bigalke 1981:22). 'Every Torajan traces descent from a number of different originhouses or tongkonan, the birthplaces of their parents, grandparents, and more distant ancestors' (Waterson 1991:163, 165). In that sense, the tongkonan represents a person's ties with his or her ancestors and contemporaries and, therefore, literally symbolizes a Torajan's place in society (Volkman 1985:52-3). The word tongkonan actually stems from the Torajan term tongkon which means 'to sit' or 'to attend' (Waterson 2009). 'In Toraja, as in much of Indonesia, where and how one sits are signs of status' (Volkman 1985:52). A pattern of social stratification of varying significance, form and intensity exists among and between the various Torajan kinship groupings. Such ranking systems are based on hereditary and often comprise three or four classes - the nobility, commoners and slaves.

Not surprisingly, tongkonan like their members are not equal in social space and are physical expressions of status differences. Through design, size, distinctive shape, and fine ornamentation, the tongkonan of the nobility are conspicuous displays of status, wealth and power. The construction and rebuilding of such enduring signs of prestige usually involve specific rituals. ${ }^{2}$ In addition, tongkonan of the nobility 'gain prestige from the myths about their founding ancestors, and from the heirloom valuables stored within them (gold and silver ornaments, swords, kerises, old Chinese porcelain, textiles and beadwork)'(Waterson 1991:65). People of high rank are often able to trace genealogical ties with a vast number of tongkonan back as far as mythological ancestors, involving up to 30 generations. For people from the lowest class (slave class), this is less

2 The Torajan rituals will be described in more detail in Chapter 6 . 
common, but they are still well aware of their genealogy. Nooy-Palm (1979a:23) asserts that 'The family tree of a person from an eminent family can fill a sheet of paper two metres wide and three metres long.'

Torajans in general distinguish among three pre-eminent lineages to which every person, house and kinship grouping in the Sa'dan highlands can be traced. ${ }^{3}$ On the basis of this descent, a person and an individual house can be ranked within the social order. Along these tongkonan lines, the first forms of wider socio-political organization began to emerge. To share the burden of comprehensive ceremonial cycles, tongkonan started to form federations under the leadership of the mother tongkonan. ${ }^{4}$ This oldest and most noble tongkonan of a kinship grouping formed the political centre and supplied the ruling chief. Most other tongkonan also held titles but less significant ones. Each titleholder had 'a specific area of competence and a concomitant role to perform in ritual (Nooy-Palm 1979a:6o). On occasion, these functionaries also met for councils to discuss war and peace and to settle disputes.

In a theoretical sense, Torajans may thus belong to hundreds of different houses. However, in practice most people are only attached to the houses of their parents and grandparents because the obligatory contributions to the expense of rebuilding and rituals discourage membership in too many houses (Waterson 1991:65). A single household typically maintains ties with four tongkonan, although this does not imply that members actually have to live in or near all these houses. 'Indeed, it can happen... that a house is left empty and not inhabited at all, and yet is still regarded as the point of origin of its descendants and as the appropriate place for the holding of ceremonies. (Waterson 1991:65).

Considering the above, it can be stated that a tongkonan is much more than a material structure or physical place; it is also the group of people who claim descent from it. The synergistic functioning of the tongkonan is depicted appropriately by Waterson (2000:177) through the following quote:

The physical and spiritual components of house value-their heirlooms, bones, and spirits of the dead as well as the placentas of the newly bornanchor people to place and to their ancestral origins. People's identities are thus grounded in the landscape, the physical house functioning as a material sign for the social memories that localize groups to certain places

\footnotetext{
3 For a more extensive account of Torajan genealogy, see Nooy-Palm 1979a.

4 'Nota van H.T. Lanting, Controleur van Makale/Rantepao', 1926, p. 6, in: KITLV, $\mathrm{D} \mathrm{H}_{7} 85$.
} 
(houses, fields, tombs). Houses create simultaneous spatial and temporal networks for conceptualizing how social groups are linked to one another, because of their references to specific historical memories of descent and affinal relationships that are construed as relationships among houses.

\section{Tongkonan Federations and Constellations}

While Torajans share a common mytho-historical origin and cultural heritage with other kinship groupings, that common heritage had undergone diversification because 'people strove to meet the locally variable demands of "place", "time" and "conditions"' (Reuter 2002:117). Throughout the Sa'dan highlands, a variety of distinguished tongkonan federations existed in the pre-colonial era. Although the socio-political organizations, and the names for these forms, varied widely, similar levels of organization started to emerge ${ }^{5}$ (see Figures 4.1 and 4.2 for an example). For the purpose of this study, it is only necessary to discuss the most important levels in more detail, namely: (1) lembang; (2) bua'; (3) penanian/karopi'; (4) borongna/ saroan. The borongna or saroan are a form of working group consisting of a few tongkonan. The penanian or karopi' are federations of tongkonan that celebrate particular rice ceremonies together. Depending on the area, the bua' and lembang are the largest genealogical and ceremonial communities that celebrate rituals of superior rank. ${ }^{6}$

Starting with the latter, the lembang is an organizational form typically found in the southern Sa'dan highlands. In this area, three of these lembang, Sangalla', Ma'kale and Mengkendek, formed a federation called Tallu Lembangna (the Three Vessels). The Tallu Lembangna are small kingdoms ruled by headmen (puang) who have genealogical, political and ritual relationships with each other (Nooy-Palm 1975:64). The unification of the Tallu Lembangna in the south of the Sa'dan highlands developed in the late thirteenth century (Liku Ada' 1986:33). In this period, the so-called 'Tomanuruns' and their descendents who came from East Java introduced a three-tiered social stratification based on blood ties in the southern region of Tana Toraja. ${ }^{7}$ This status system was the basis of a political

5 'Nota van H.T. Lanting, Controleur van Makale/Rantepao', 1926, p. 7, in: KITLV, D H 785 .

${ }^{6}$ Sometimes lembang are called patang penanian, an organization of four penanian (Nooy-Palm 1975:64).

7 According to Torajan belief, three Tomanuruns were sent down from heaven. This mythology is shared by the other people in South Sulawesi. Where the Tomanuruns really came from is still uncertain but according to Salombe', they may have come from East Java during the reign of Kertanagara, the last King of Singhasari (Salombe' 1984 in Liku Ada' 
organization in which a number of communities cooperated in organizing ceremonies. These communities were ruled by so-called puangs, descendants of the tomanurun who formed an elevated supra-tier above the three-tiered stratification system. This model of political organization and social stratification took hold only in the southern region of the Sa'dan Toraja. Puangs had strong authority because blood ties became the determinant factor of status and mobility between the different classes rarely occurred.

One of the villages in this study, Palipu', was established in this southern region. Palipu' once existed only in a genealogical form. According to mythology, the first inhabitant, named Darra' Matua, came to the region of present-day Palipu' some twenty generations ago. Darra' Matua is believed to have been a descendant of Tamboro Langi', the first Torajan man who arrived on the mountain peak of Kandora after being sent down from heaven. Darra' Matua had three children who each established a tongkonan house at the foot of Kandora Mountain. Once the family in these tongkonan became too large, some descendants would build a tongkonan for themselves in the vicinity of the mother-houses. Gradually a kind of ritual community started to emerge that covered several tongkonan. This ritual community, or penanian, carried out ritual obligations together and became known as the 'large bamboo rice basket', or Palipu'8 Some time later, the tallu lembangna absorbed the smaller communities within their territories. Together with eight other penanians, Palipu' was incorporated in the statelet, or lembang, of Mengkendek, one of the three tallu lembangna. Within the lembang of Mengkendek, Palipu' constituted the Tallu Penanianna, sesena Mengkendek (meaning the three Penanian, the half of Mengkendek) along with two other penanian (Tengan and Marinding). The three penanian were under the authority of papalumbanga, $n^{9}$ who assistedthe puang of Mengkendek in maintaining complete control over the whole lembang.

1986:28). According to Ramstedt, the direct relationship between the highlands and Majapat is highly speculative. Instead he proposes Bugis Bone as a more direct transmitter of Old-Javanese influence (for more details, see Ramstedt 2004:197).

8 In Mengkendek, the region that encompasses Palipu', the penanian community stages a ritual called ma'bugi'. '[T] the ma'bugi' functions to purify the traditional community. It removes the pollution which constantly accumulates during the course of everyday life.... Poor rice harvests, ill domestic animals, sickly children, and such are all external signs that the accumulation of pollutants has become burdensome (Crystal and Yamashita 1987:61).

9 'The title, Pa'palumbangan can be paraphrased as "The piling up of rice bundles on the sawah dike". [T] he title embodies a notion derived from the cultivation of rice. The Pa'palumbangan arranged all transactions related to the internal organization of the region, and he also rallied the people in times of war...' (Nooy-Palm 1979a:76). 


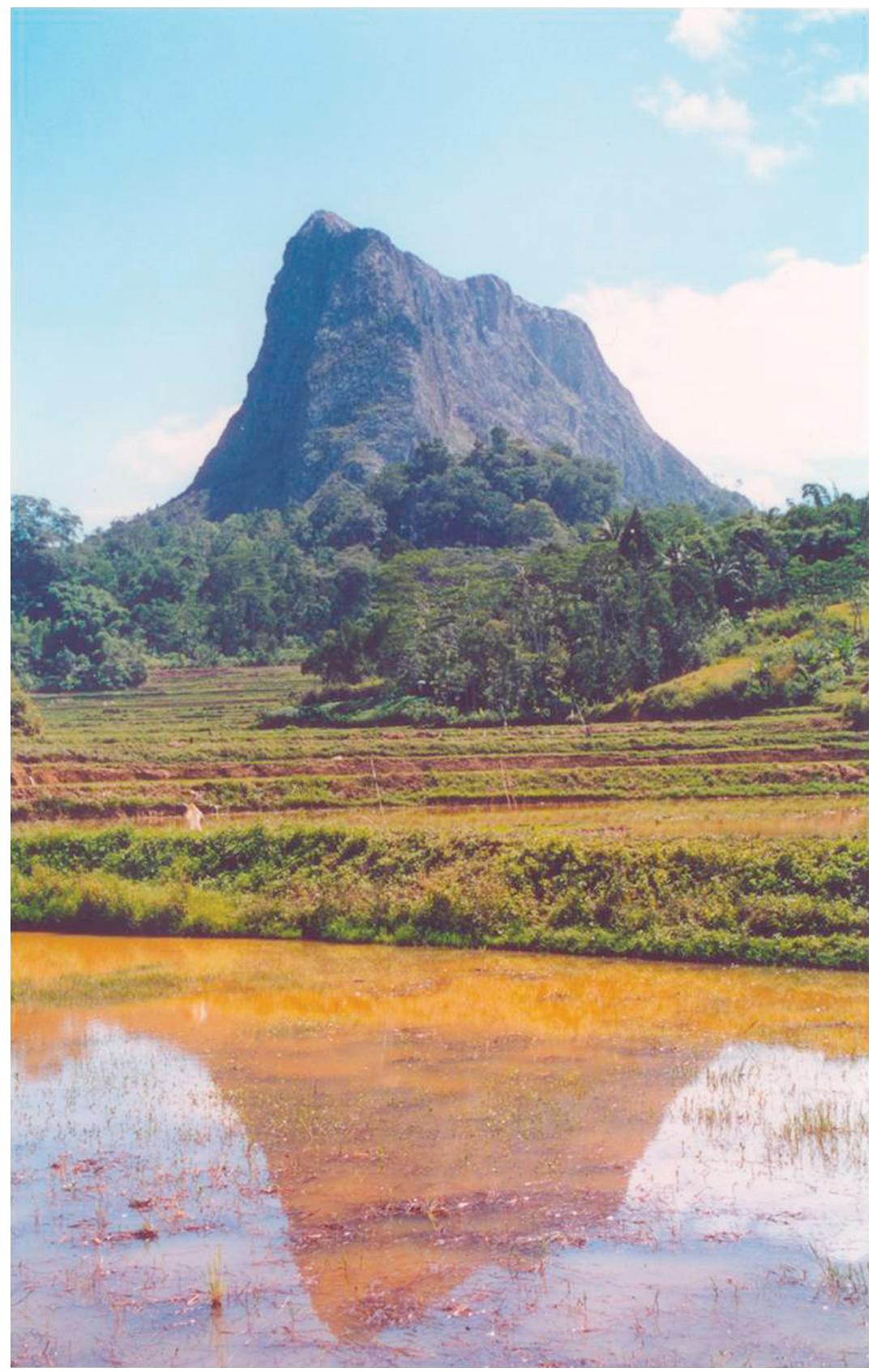

Ill. 4.1. Mountain Kandora', next to the case study village Palipu' (photo by Wendy de Jong-Jakobs). 
Despite Palipu's incorporation into lembang Mengkendek, Palipu' largely maintained its autonomy, and its struggles to remain outside the puangs' spheres of influence in the subsequent period succeeded. However, since the late nineteenth century, a series of conflicts over land has changed the situation in Palipu'. One of the bitterest issues arose when puang Randanan of Mengkendek confiscated almost all of Palipu's wet ricefields. The majority of Palipu's population lost their ricefields and fell to the mercy of the descendants of puang Randanan who had founded three tongkonan in the settlement. With the arrival of the puang family in Palipu', a fourth social class was added to the existing social strata. The puangs acquired the highest positions, even above the nobility who also had to hand over many of their ricefields to the puangs. However successful they may have been in politics, the puang family never managed to obtain complete control in the ritual community.

Because the total number of tongkonan in Palipu' continued to grow, the penanian was subdivided into four borongna, meaning section or sharing group..$^{10}$ It is not clear whether these borongnas were already constituted before the large land takeovers at the end of the nineteenth century, but they mainly had a ritual function and facilitated the mobilization of people during conflicts and times of war. When one of the borongnas became too large, it was subdivided into six banua tallu, meaning 'three houses', and, not surprisingly, these encompass three tongkonan and

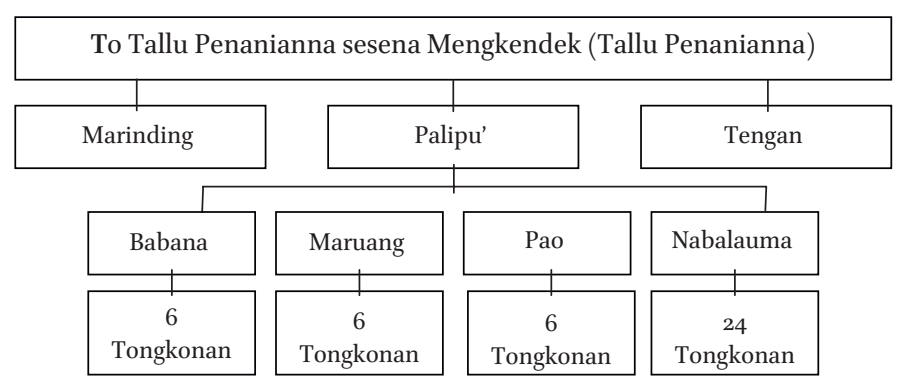

T. Penanianna

3 Penanian

4 Borongna

40 Tongkonan

Figure 4.1. Traditional socio-political divisions in the socio-ritual community Tallu Penanianna: the situation of Palipu'.

10 A borogna is sometimes also referred to as a tepona padang, meaning four pieces of land. However, this type of community does not tally with the tepona padang that can be found in the northern areas of Tana Toraja. The four borongna in Palipu' are named Babana, Maruang, Pao, and Nabalauma and seem closer to the saroan in the North. 
their families. This social unit has only a ritual function and remains the smallest subdivision today (see Figure 4.1 for an overview of the socialritual organization in Palipu').

Descendants of the puangs from the South also entered the northern parts of the Torajan highlands. However, these communities appear to have been far less structured in a territorial and organizational sense, and were simply led by family heads. Compared to the more densely populated southern area, where a kind of headed penanian and lembang had developed to which they could ally themselves through marriage, the conditions in the North were unfavourable for the puangs obtaining a firm position. ${ }^{11}$ According to Lanting, the lack of puangs in the northern regions can be attributed to the formlessness of these regions when the puangs arrived. The puangs of the south could not establish themselves as the heads of developed communities and instead merged with the existing leaders of the highest class in the North;- the level of the tomaka. As a consequence, a fourth tier did not emerge in the north of Tana Toraja.

In this context Kondo, the other research village in this study, came into being. According to Torajan mythodology, Puang ri Kesu', one of the decendants of Tamboro Langi' (the first Torajan man), settled more than 20 generations ago in Angin Angin, in the north of present-day Tana Toraja. This tongkonan is considered to be the oldest ancestral house (tongkonan layuk) in the northern part of Tana Toraja, and all northern communities have ties to it. One of the descendants of Puang ri Kesu', Polo Padang, founded tongkonan Rante Aa, on Mountain Rangri, a few generations later. From this tongkonan, descendants spread out in all directions over a radius of about ten kilometres and built their own tongkonan. ${ }^{2}$ These people are the ancestors of a group of six bua' communities that includes Tondon, in which the village of Kondo' is located. ${ }^{13}$ A bua' community amounts to a territorial area within which the inhabitants celebrate together the bua' padang ritual 'which is a kind of agricultural new year celebration with the aim of imploring the higher powers to smile on man, beast and the produce of the fields (in this instance, rice)' (Nooy-Palm 1979a:61). In practice, the people of these various bua' communities still

11 'Nota van H.T. Lanting, Controleur van Makale/Rantepao', 1926, p. 21, in: KITLV, D $\mathrm{H}_{7} 85$.

12 Polo Padang had eight children who built themselves tongkonan in Bokin, Bori, Sa'dan, Karua, Nanggal, Seko, Ba'tan and Rangri.

13 These bua' are Buntao, Bokin, Nanggala, Balusu, Talunglipu and Tondon ('Nota van H.T. Lanting, Controleur van Makale/Rantepao', 1926, p. 22, in: KITLV, D H 785). 
maintain close relations with one another through inter-marriages and debt exchanging at funeral ceremonies.

The bua' community of Tondon is located just north of Rangri Mountain and was founded by $\mathrm{Ne}^{\prime} \mathrm{Malo}$, one of the descendants from tongkonan Rante Aa. The four sons of Ne' Malo spread out over the region of Tondon, and each established their own tongkonan. This splintering process eventually led to the emergence of a socio-political organization that consisted of four tepona padang, each further divided into three karopi'. The tepona padang were each headed by three tongkonan leaders (to 'parenge') and one ritual leader, or sokkong bayu, who were collectively responsible for daily affairs. If they could not reach an agreement, the heads of the six most prominent tongkonan in Tondon intervened and took the final decision. ${ }^{14}$ At this time, leadership was not set and people had to keep on fighting to defend their positions. It was literally the survival of the fittest. The class system in the north of Tana Toraja was somewhat dynamic, and inhabitants had the chance to acquire status by creating wealth or showing their bravery during wars, which made the northern elite politically vulnerable (Bigalke 1981:20).

The village of Kondo' corresponds with one of the three karopi' in the tepona padang Mata' allo (see Figure 4.2). Like all twelve karopi' in the bua' of Tondon, Kondo' was headed by a to'parenge', the chief of the most important tongkonan in Kondo'. The to'parenge' also sits on the council of the teponna padang Mata'allo, representing his karopi'. At a large bua' feast, encompassing the whole community of Tondon and held at its founder's tongkonan, the people of each tepona padang were seated along one side of a square ceremonial field. This symbolized the equal status of the four tepona padang. Still today, the people of the three karopi' that make up one tepona padang have stronger ties with each other than with people from other tepona padang. Similarly, the people within the bua' of Tondon have stronger relations with each other than with people from other communities. They feel closer to the bua' communities originating from the tongkonan at Rangri Mountain than to those who do not have any relationship with this tongkonan. In the past, people from Tondon have allied themselves with various bua' communities to resist Bugis attempts to conquer the highlands, ${ }^{15}$ and this has strengthened the

14 Of these six tongkonan, the three most important ones were: Ne' Mala, Ne' Paraba and To' Pajoengi.

15 One of the most successful defences against invading Bugis armies had been against the attack under the leadership of the Bone raja Arung Palaka in the late seventeenth century. Tondon fought side by side with people from the bua' Sa'dan, Balusu and Nanggala. 


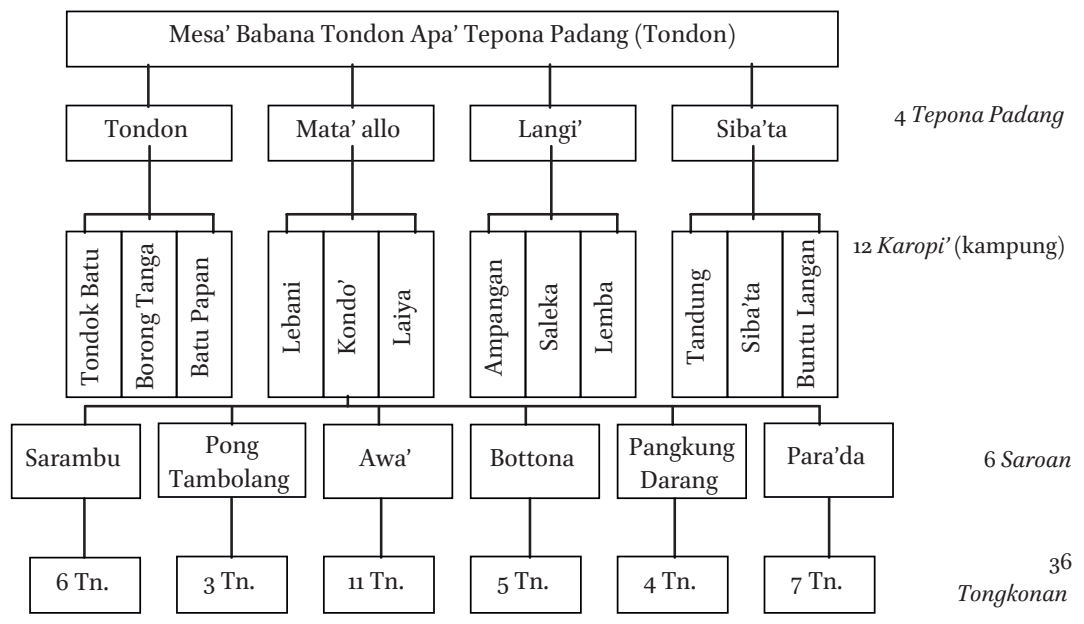

Figure 4.2. Traditional socio-political divisions in the socio-ritual community of Tondon: the situation of Kondo'.

bonds between these bua' communities and people from Tondon even further.

The headman, or to parenge', of Kondo' administered the law within the karopi's boundaries, and chaired the karopi' council which was made up of noble people and village elders. Some of these leaders were also heads of the six indigenous labour institutions in Kondo', the so-called saroan. ${ }^{16}$ The saroan is the most important collective social network above the level of the tongkonan and below the karopi'. It is difficult to describe the shape of a saroan and to distinguish it from a tongkonan in terms of membership. Ideally, all members of a saroan descend, as do members of a tongkonan, from a common ancestor (Volkman 1985:77). A closer look at saroan, however, reveals that neither territory nor kinship adequately define their shape. Distant relatives or non-kin living in the neighbourhood of a particular saroan may become active members while membership may extend beyond the immediate territorial centre and,

16 Although the terms used for referring to this kind of mutual support group differs by territory, saroan is the most frequently used term throughout Tana Toraja. In the northern region of the regency its usage can be found most frequently. In the southern research area, the same kind of mutual support group was called a borongna. While elaborating on these collective social networks, I use the widely known term saroan to prevent any confusion. 
conversely, not everyone in that territory is necessarily a member. In this way, the saroan is more open than the tongkonan, which is impossible for outsiders to join (except through marriage or adoption). Volkman (1985:78) reports that Torajans do not define the saroan by what it is (based on territory or kinship), but rather by what it does: 'Saroan labour is based on a spirit of cooperation, the famous Indonesian gotong royong.' ${ }^{17}$ Saroan were established as communal labour groups to lighten heavy tasks related to agriculture, house building and ceremonial activities. They also functioned to seize prisoners in warfare or in the event of abductions of slaves and theft of buffalo by neighbouring groups. According to a local legend, the karopi' community of Kondo' had been seized by people from Awan (western part of the Torajan highlands) about ten generations ago. These people took over control and demanded the best buffalo (saleko) that the people of Kondo' possessed and even took the best looking women to become their wives. The people of Kondo' could do nothing but comply with the demands of their conquerors because the rulers from Awan were strong and brave. To find a way out of this precarious situation, the people of Kondo' organized themselves into six groupings or saroan. Under the leadership of Ne'Madoi and Ne'Tappi, representing the tongkonan of the brave in Kondo', they defeated the tyrants of Awan. Afterwards, the saroan remained intact, and were often needed to hold back Bugis intruders or against attempts by neighbouring communities to capture weak inhabitants for the slave trade..$^{18}$

Nowadays, the saroan fulfils a vital function, especially in ritual life. It is responsible for erecting all the temporary constructions required at rituals performed by saroan members, and it carries out all other labour tasks involved in the preparations, as well as during the ceremonial activities itself. Most importantly, the saroan is also the group among which meat is divided, the group that eats together (see also Volkman 1985:79). The saroan, or rather its chief ( $a m b e$ ', literally 'father') regulates the distribution of meat, both among its own members and between itself and other saroan. The chief of a saroan knows each household, its composition, ancestors, wealth and previous meat-cutting record. Membership in a saroan is not listed individually but by household. Usually membership is inherited by both male and female children from their parents, but

\footnotetext{
17 Gotong royong refers to mutual cooperation.

18 I have some indications that the people from Kondo' also sold the weak and enslaved to Bugis traders.
} 
upon the establishment of a new household, the newly wed couple chooses the saroan they prefer, usually based upon the area in which they live.

Until the Dutch entered the highlands, this system of organization remained largely unchanged through the karopi' of Kondo' and larger bua' of Tondon. Considerable land seizures, as occurred at the end of the nineteenth century in the southern parts of Tana Toraja, did not take place in this region. While chiefdom was largely determined by bravery displayed during wars, with leadership more fluid in the northern region of the Sa'dan highlands than in the authoritarian south, northerners tended to cling to the original, loosely structured, social organization. Consequently, socio-political organization in the south of Sa'dan Toraja became more developed than in the north. The further you move south, the more complex and sophisticated societies become. ${ }^{19}$

Summing up, early Sa'dan Toraja was subdivided into a number of distinct social units. Each community was internally divided into lineages and segments of kin, which were connected to similar units by a network of collective ties. Torajan society is cognatic, but at the same time consists of a form of linear descent groups (tongkonan). These descent groups function more or less like 'quasi lineages' and also have a corporate character. Although names and forms varied widely, the lembang/bua', the penanian/karopi', and the borongna/saroan could be seen as on a similar level of social organization. Grounded on mythical common ancestors, the Sa'dan highlands consisted of three larger circles (North, South, and West) which were composed of similar bua' units and lembang in terms of name, form and socio-political organization. Within each social group, positions of authority were primarily defined by descent and caste. Each group as a whole had a leader or symbolic head, but nonetheless they regulated common affairs collectively. Except for the Tallu Lembangna, sociopolitical organization was not territorial but rather largely genealogical in the Sa'dan highlands.

19 The western part of the Sa'dan highlands was also made up of tongkonan with long histories that led to another federation of three lembang (Adaatstaatsrecht Loewoe 1947:39). However, due to Bugis attacks at the turn of the seventeenth century, this federation disintegrated, and the western region of the Sa'dan highlands became largely subjected to the earlier described Tallu Lembanga in its southeast region and the neighbouring region of Mamasa on its west side (Bigalke 1981:25). With regard to social structure, ceremonial activities, house construction and other cultural aspects, people in the west of Sa'dan Toraja are closely related to the Mamasa people, or Toraja-Mamasa (Van der Veen 1929:61). 


\section{The Making of a Colonial Toraja}

The situation as described in the first part of this chapter changed dramatically in 1906 when the Dutch entered the Sa'dan region. At the beginning of the twentieth century, on the 'outer island' of Sulawesi, the Dutch only ruled the northern region (Minahasa and Gorontalo) and around Makassar in the southern part of the island. As Roth (2004:163) put it 'The highland regions of South and Central Sulawesi remained a white spot on the maps of the colonial administrators until well into the nineteenth century'. In line with the pacification policies of the Dutch government, South Sulawesi was brought entirely under colonial administration between 1905 and 1906 (Plaisier 1993:35). The lowlands of Bone, Sidenreng, Gowa and Luwu were brought under Dutch control with relative ease. After heavy fighting the Sa'dan highlands followed by late-1906 (Morrell 2001:4). In this section, I expand on the first two decades of Dutch administrative engineering in the Sa'dan highlands. During this period, a handful of administrators set out to build a modern government system, as laid down in the Dutch policy for colonial Indonesia, within the boundaries of traditional socio-political organization.

After the monarch of the neighbouring kingdom of Luwu signed a 'Short Declaration' on 19 September 1905, the Sa'dan highlands were incorporated within the colonial administrative structure as two subdivisions (Onderafdeeling) in the division (Afdeeling or Zelfbesturend Landschap) of Luwu. Luwu was placed directly under the authority of the Dutch colonial government. ${ }^{20}$ However, unlike the self-government (Zelfbestuur) seen in Luwu, the Dutch civil service (Nederlandsch-Indisch Binnenlandsch Bestuur) exercized actual power in the Sa'dan subdivisions (Bieshaar 1940:27; Adaatstaatsrecht Loewoe 1947:43). The two subdivisions of Makale and Rantepao were both governed by a Dutch ruler (controleur). The subdivision of Makale included the southern Tallu Lembangna and the western area of the highlands, ${ }^{21}$ while Rantepao comprised the northern and central parts of the Sa'dan lands.

20 The Dutch colonial government approved a political contract with Luwu in 1888 in which the 'Sa'dan lands' were considered to be part of Luwu (Van Lijf 1947-1948:530; Adatstaatsrecht Loewoe, 1947, p. 42, in: KITLV, D H 907). The contract was based on the statements of the Governor of the Celebes (South Sulawesi) who obtained his information from informants in Palopo' (Luwu). In 1905, the Dutch government still had no other understanding of the situation, and the Sa'dan highlands became part of the division Luwu. The people of Sa'dan Toraja, however, never accepted their official subordination.

${ }^{21}$ As noted earlier, the western region of the Sa'dan highlands originally belonged for the greater part to the Toraja Mamasa region, at least from a cultural standpoint. However, 
Between 1907 and 1910, the Dutch started to create strict boundaries in the Sa'dan highlands-carved into various districts, sub-districts and villages - with a local-level administration (Volkman 1985:30). When subdividing the Sa'dan region, Dutch administrators tried to take both authority structures and shared customs (adat) into account. ${ }^{22}$ However, the first of these authority structures seemed to prevail, for example by taking the capturing of some Sa'dan tondo $k^{23}$ by other tondok during the civil wars of the late nineteenth century for granted. ${ }^{24}$ Notwithstanding the efforts of the Dutch to take local factors into account, the delineation of fixed boundaries remained alien to the Torajan way of defining power, which was centred on tongkonan rather than bounded by geography.

As of 1910, the Makale subdivision was composed of 14 districts (landstreken) and the subdivision of Rantepao of 17 districts. ${ }^{25}$ The districts largely matched traditional lembang, federations of bua'-circles, or single bua'-communities, and they were usually headed by traditional Torajan leaders. ${ }^{26}$ District heads were officially elected by the adult male population but the Dutch controleur retained the right to declare him 'fit' or not (Bigalke 1981:126). The 31 districts varied widely in size (800 to 34,000 inhabitants) and in structure. Accordingly, the number of administrative units below the district level differed throughout the highlands.

In Dutch colonial Indonesia, the kampung was the smallest and often the only legal unit of colonial administration below the district level.

afraid of reprisals from the Dutch military, because their kin-groups in the Mamasa area heavily opposed the pacification acts of the Dutch, they requested incorporation within the subdivision of Makale (Adatstaatsrecht Loewoe, 1947, pp. 42-3, in: KITLV, D H 907).

22 'Nota van H.T. Lanting, Controleur van Makale/Rantepao', 1926, pp. 4-7, in: KITLV, D $\mathrm{H} 785$.

${ }^{23}$ While Torajan social organization slowly moved to a territorially based one, for a long time they had had a concept of territorial organization, implicit in the idea of tondok (Bigalke 1981:28). Whereas the bua' and lembang are social organizations based on ritual cycles that possibly (but not necessarily) develop into territorial organizations, a tondok is a territorial unit in its most elementary form. Tondok can roughly be translated as 'village', but it comes closer to the Indonesian term of kampung (settlement) (Bigalke 1981:28). The tondok is composed of a cluster of houses (including tongkonan) representing one or more kinship groups with an acknowledged headman for both the religious and political realms.

24 Adatstaatsrecht Loewoe, 1947, pp. 39-40, in: KITLV, D H 907.

25 The subdivision of Makale comprised the following districts: (1) Makale; (2) Sangalla; (3) Mengkendek; (4) Taparang; (5) Banga; (6) Malimbong; (7) Taleong; (8) Palesang; (9) Buakayu; (10) Rano; (11) Bau; (12) Mappa; (13) Balepe'; (14) Simbuang. The Subdivision of Rantepao Contained: (15) Tikala; (16) Kesu'; (17) Pangala'; (18) Sa'dan; (19) Balusu; (20) Tondon; (21) Nanggala; (22) Buntao; (23) Rantebua'; (24) Madandan; (25) Piongan; (26) Kurra'; (27) Ulusalu; (28) Seseng; (29) Bittuang; (30) Balla'; (31) Pali ('Nota van H.T. Lanting, Controleur van Makale/Rantepao', 1926, in: KITLV, D H 785.).

26 'Nota van H.T. Lanting, Controleur van Makale/Rantepao', 1926, in: KITLV, D H 785. 
As Sa'dan Torajans were not familiar with this concept, the political reality of the kampung had to be created by drawing neat lines around tongkonan and tondok. Sometimes, one kampung would be composed of several tondok but with only one kampung head, elected by all adult males. ${ }^{27}$ As a rule, the kampung head had to be a descendent of a high-status family and was usually the titleholder of an important tongkonan. A kampung council composed of tondok leaders assisted the kampung head (Kennedy 1953:149). During this period, the Dutch administrators created about 400 kampung in the two Subdivisions (Van Lijf 1947:100).

In some districts, especially in the oldest and most complex Tallu Lembangna, two administrative levels were set up between the district and kampung levels: 'complexes' and 'sub-districts' (onderdistrict). A complex usually matched a larger bua' community, comprising several kampung. A sub-district amounted to a federation of bua' circles. However, sub-districts were only established in the district of Makale, one of the Tallu Lembangna. In detail, the district of Makale consisted of four subdistricts, four complexes and several kampung. ${ }^{28}$ The head of a complex was often also the head of a kampung, and a few of them had other kampung heads below them. Initially, the Dutch introduced four complexes in the subdivision of Rantepao and 24 in the subdivision of Makale but, due to financial reasons, the Dutch systematically deconstructed both complexes and sub-districts after $1930^{.29}$ By 1940 , only 17 out of 28 complex heads were still in office, and all sub-district heads had disappeared, largely because the Dutch were of the opinion that this function lacked any roots in the adat..$^{30}$

The situation in Palipu' remained pretty much unaltered. The puang family still held political power, and the families that were long rooted in Palipu' occupied most of the important social and cultural (adat)

27 G.R. Seinstra, 'Memorie van overgave betreffende de onderafdeelingen Makale en Rantepao van den aftredenden Controleur bij het Binnenlandsch Bestuur. Bestuursperiode 18 juli 1935-1 januari 1940', 1939, p. 131, in: Nationaal Archief, Den Haag, Ministerie van Koloniën: Memories van Overgave, 1852-1962, nummer toegang 2.10.39, inventarisnummer 1164.

28 'Nota van H.T. Lanting, Controleur van Makale/Rantepao', 1926, p. 11, in: KITLV, Leiden, D H 785 .

29 Adatstaatsrecht Loewoe, 1947, p. 49, in: KITLV, Leiden, D H 907; Van Lijf 1947:99.

30 G.R. Seinstra, 'Memorie van overgave betreffende de onderafdeelingen Makale en Rantepao van den aftredenden Controleur bij het Binnenlandsch Bestuur. Bestuursperiode 18 juli 1935-1 januari 1940', 1939, pp. 130-1, in: Nationaal Archief, Den Haag, Ministerie van Koloniën: Memories van Overgave, 1852-1962, nummer toegang 2.10.39, inventarisnummer 1164 . 
positions. Representatives of the twelve most important tongkonan in Palipu' (including that of the puangs) were seated in a kombongan. This council of elders and chiefs ruled ritual affairs and settled conflicts over issues such as divorce, inheritance and land. Initially the Dutch kept this system largely untouched and turned the penanian of Palipu' into an administrative division of a complex under the landstreek of Mengkendek. This was also the first time that the territory of Palipu' had been clearly delineated by Dutch officials.

Compared to the communities in the southern division of Makale, that were already moving over to territorial units, communities in the northern part of the highlands retained much more of their original shape. ${ }^{31}$ For example, the bua' of Tondon remained intact and became a district (landstreek) after the Dutch delineated the Torajan highlands. ${ }^{32}$ The district was ruled by a head with the title of to parenge', descended from one of the most important tongkonan in the bua'. The four tepona padang were converted into four kampung. The heads of these kampung assisted the to parenge' in governing the district. There were no administrative divisions below the level of the kampung, thereby ignoring the karopi'.

Despite all these administrative changes, the Dutch wanted to retain the traditional status system (Volkman 1985:30). Nevertheless, the introduction of democratic elections, open to all adult males, had the potential to undermine the existing social order. Giving the lowest status groups, or slaves, a right to vote conflicted with Torajan customs which stated that only particular high-class leaders were entitled to vote. ${ }^{33}$ Moreover, Dutch officials observed that slaves adversely influenced elections by voting for the weakest candidates. As a consequence, the general ballot was abolished and political decisions were again made by the high-class elders who joined in traditional committees, or kombongan: keeping social-class differentiation alive and probably even reinforcing it.

With the introduction of central government control and an ordered administration, the Dutch created conditions under which education, healthcare, agricultural extension and a cash economy could flourish (Van Lijf 1951:357). Moreover, the door was opened for the Christianization of the highlands. Government officials were concerned that Islam, the dominant religion in South Sulawesi, would further penetrate into the Sa'dan

31 'Nota van H.T. Lanting, Controleur van Makale/Rantepao', 1926, in: KITLV, D H 785.

32 The delineation of the Torajan highlands is recorded in an official bulletin (Staatsblad, no. 352) in 1916.

33 Adatstaatsrecht Loewoe, 1947, p. 50, in: KITLV, D H 907. 
highlands and encouraged missionary societies to take an interest in the region. In 1913, the government started to lay the foundations for establishing Christianity in the highlands through the Calvinist Missionary Association (GZB) ${ }^{34}$ (Bigalke 1984:89). Close cooperation between government and missions was supposed to bring about fundamental changes in the highlands.

The missions introduced education as a way of entering traditional societies without creating the type of resistance that would be engendered by a direct attack on traditional religious values (Bigalke 1984:90). Headmen who refused to cooperate with the GZB were selectively removed and exiled by the Dutch government. Increasing interference by missionaries and government in village affairs, together with the growing fear that the Dutch were trying to destroy indigenous religion, led to mounting opposition among Torajan leaders. The indigenous religion of the Torajan people, which is often called Aluk to dolo (Way of the ancestors), refers to the way in which both rituals and daily life are to be conducted; it is an all-embracing way of life. The Tondon elites remained especially hostile to the missionaries and were the first to refuse to provide labour and materials for use in school construction. Tondon 'remained a bitter source of complaints, ostensibly over a misunderstanding between the chief and a guru from the government school in Rantepao' (Bigalke 1981:182). In reality the conflict ran deeper than that, and the missionary Van der Loosdrecht remarked that 'a spirit of quiet rebellion rules in Tondon' (Bigalke 1981:182). The Torajan elites, who saw their position endangered by the mission that attacked the very basis of the social hierarchy, eventually started a small Torajan rebellion in mid-1917 during which the missionary Van de Loosdrecht was murdered (Bigalke 1981:104).

Aware of the fragility of a bureaucracy managed and supported by just a few Dutch officials, the Controleurs of Rantepao and Makale issued orders that prevented any further undermining of the traditional elite, as their support seemed to be essential for law and order to prevail in the region (Bigalke 1984:111). Consequently, most village heads continued to maintain authority despite the influence of the Dutch. These changes in government policies resulted in a neat differentiation between the compulsory power of the Dutch government in Makale and Rantepao and the persuasive authority of the mission (Bigalke 1984:112). The mission continued to provide a channel for middle and lower class villagers to oppose the

34 Roman Catholic missionaries entered Makale-Rantepao in 1938 after the Dutch government started to allow ‘double Missions' (Van Lijf 1951:366). 
prevailing social hierarchy, but it had to leave room for the village elite to reject the advances of missionaries and teachers.

After 20 years of Dutch administration, some of the traditional forms of kin-based socio-political organization had faded away and the transition toward territorial communities had accelerated. Nevertheless, Bigalke (1981:121) wrote that Torajans still praised the accuracy of Dutch administrators in subdividing the Sa'dan highlands into districts. The differences between the northern and southern regions of the Sa'dan highlands were also acknowledged by the Dutch and consequently consolidated into two different administrative divisions. The political authority of traditional Torajan leaders was re-established after temporarily being endangered through the interference of the mission. In practice, the heads of the newlyestablished districts, sub-districts, complexes and kampung could not be differentiated from adat leadership.

Between the 1920s and the Japanese invasion in 1942, the Dutch regularly considered reducing the large number of administrative territories in the Sa'dan highlands due to financial constraints. However, the arguments in favour of amalgamating administrative units were not very compatible with Torajan adat, and large-scale centralization never really succeeded. ${ }^{35}$ Although the Dutch did manage to unify the subdivions of Makale and Rantepao under the leadership of one controleur in 1927, initially the cultural demarcation between the northern (Rantepao) and southern (Makale) regions remained firm. ${ }^{36}$ Later, some of the educated elites started to mix in the newly created towns of Rantepao and Makale, which belonged to no individual kinship group but were a purely Dutch creation. In 1934, the 'modern' elites of Rantepao founded an organization, Perhimpoenan Boenga' Lalan (PBL), with the objective of building a brotherhood among the Torajan people so that they could be united (Bigalke 1981:297). This was the first time that Torajans had openly conceived of themselves as a common group of people from a land (tanah) which they called 'Tanah Toradja. ${ }^{37}$

35 G.R. Seinstra, 'Memorie van overgave betreffende de onderafdeelingen Makale en Rantepao van den aftredenden Controleur bij het Binnenlandsch Bestuur. Bestuursperiode 18 juli 1935-1 januari 1940', 1939, p. 126, in: Nationaal Archief, Den Haag, Ministerie van Koloniën: Memories van Overgave, 1852-1962, nummer toegang 2.10.39, inventarisnummer 1164 .

36 The new subdivision of Makale-Rantepao remained part of the Luwu division. The Torajan people, however, rejected the self-government of Luwu, and the Dutch civil service retained the actual political power in the highlands (Van Lijf 1951:370).

37 During the colonial period, Toraja was written as 'Toradja' and Tana as 'Tanah'. Although I adapt the term according to its usage in a particular government era, they both have the same meaning. 
Two years later, a group of young Torajan Christians with various educational backgrounds established the organization Perserikatan Toradja Christen (PTC) in Makale, with the objective of uniting a still-divided Torajan people (Bigalke 1981:298). The real, more covert, intention of the PTC appeared to be separation from, and gaining equal status to, Luwu (Bigalke 1981: 303). The demand for a separation of Tanah Toradja from Luwu was a step toward the ultimate goal of incorporating all highland groups of Central and South Sulawesi into a Greater Toradja, or Toraya Raya (Bigalke 1981:304; Kobong 1989:86-7). The Mission, which initially launched the idea of a Greater Toradja, consisting of all Christianized Torajan mountain peoples of the Sa'dan, Mamasa and Poso areas, in 1932, supported this demand. Anti-Bugis sentiment was growing in the highlands, and the age-old political, social, economic and cultural-ritual relationships between the Protestant Torajan highlands and Islamic lowlands of Luwu were increasingly conceptualized in terms of 'ethnic' identity with religion as the main boundary marker (Roth 2002, 2004). The Dutch government, afraid of running into conflict with the ruling house of Luwu, generally opposed demands for an independent Tanah Toradja. Nevertheless, a political basis for a united Sa'dan highland was established, and the call for an independent Tanah Toradja was growing.

With the Japanese invasion in 1942, 36 years of Dutch rule came to an abrupt end, leaving a political vacuum in the highlands (Bigalke 1981:312). The centralized administration, installed by the Dutch, began to unravel, and some district chiefs tried to claim authority beyond that granted by the Dutch administration. According to Bigalke 'internal rivalries between Rantepao and Makale as well as among their various districts foreshadowed the return to the pre-1906 condition of petty principalities among which the larger districts would play dominant but not unchallenged roles. At this point Luwu intervened to reassert Luwu's authority over Makale-Rantepao and to maintain the integrity of Division (Afdeeling) Luwu in the face of purposeful but disorganized attempts to divide it' (Bigalke 1981:317).

Luwu encountered strong resistance from the entire Sa'dan Torajan population among whom desire for separation increased (Van Lijf 19471948:533). However, their lack of unity prevented a coordinated effort to assert and maintain the political autonomy of Makale and Rantepao (Bigalke 1981:318). Like the Dutch, Japanese authorities initially adopted an attitude of reconciliation toward both parties and, on the whole, the Japanese administration was not much different from the Dutch. Later the system evolved into a means to supply a war machine, and the Japanese occupation became a 'time of deprivation, primitivity, violence, and the 
first unravellings of social order' (Volkman 1985:38). Overall, after 39 years of Dutch and Japanese occupation, Makale and Rantepao still seemed to be a loose collection of stateless societies, despite all those years of 'Dutch administrative engineering' (Bigalke 1981:313). The planned social and political changes of the Dutch colonial government, through government reforms (decentralization), emancipation (ontvoogding) of the Indonesian government, educational politics, and so on, never effectively reached the highlands of Sa'dan Toraja (Van Lijf 1951:370).

\section{Torajan Politics under the New Republic}

\section{The Emergency of Tana Toraja}

After the Japanese surrender, Sukarno and Hatta proclaimed Indonesia's independence on 17 August 1945, and a national revolution started against the Dutch, especially in Java and Sumatra (Volkman 1985:40). In these critical months, the self-government of Luwu fell under the influence of the Republican Party (Partai Nasional Indonesia), and its brigands started to raid the neighbouring Sa'dan highlands. ${ }^{38}$ Makale-Rantepao managed to resist the raids by the lowland nationalist bands, but highland-lowland tensions heightened once again. Although a small nationalist movement had grown in Torajan towns, most Torajans feared Muslim domination within an independent Indonesia and welcomed the reestablishment of Dutch authority in the highlands at the end of 1945. Dutch military forces crushed the small, localized movement with nationalist inspirations in Makale and Rantepao, and law and order was restored in the highlands by the beginning of 1946 .

The four years of Dutch rule that followed again marked a period of rapid administrative transition in which the subdivision of MakaleRantepao became a highly autonomous division within the Province of South Sulawesi (Residentie Zuid-Celebes). Conscious of the great diversity of regions and of peoples in post-war Indonesia, the Dutch government tried to rapidly form a sovereign democratic state on a federal basis (Legge 1961:4). In a revolutionary period, when a wise application of 'divide and rule' was needed to create a federal Indonesia, the Dutch recognized that further decentralization was inevitable (Bigalke 1981:367). The Dutch rush to implement far-reaching regional autonomy and local self-governance, together with the longstanding Torajan aspirations to

\footnotetext{
38 Adatstaatsrecht Loewoe, 1947, p. 43, in: KITLV, D H 907.
} 
separate from Luwu, led to the realization of the autonomous Selfgoverning Division (Zelfbesturend landschap) of Tana Toraja in October 1946 (Van Lijf 1947:91; Liang Gie 1993:167-75).

One of the major obstacles that had prevented the separation of Tana Toraja before the war had finally been overcome: the lack of harmony among Torajan district heads and a strong 'region-patriotism' (Van Lijf 1947:95). Through a complex procedure, seven out of the 30 Torajan district heads were chosen as representatives in the signing of the Short Declaration that validated Tana Toraja as a self-government area. By mutual agreement, these seven district heads were appointed as members of the executive council of Tana Toraja, Tongkonan Ada'39 (Van Lijf 1947:91). The further development of the self-government of Tana Toraja took place under the leadership of a Dutch controleur who had transferred all his authorities to the Tongkonan Ada' by 27 July 1947.

By then, Tana Toraja had become $3^{2}$ autonomous districts (see Map 4.2), or so-called lembang, under the leadership of 30 lembang heads (2 lembang heads supervized each 2 districts). The lembang possessed autonomy in all affairs that did not impinge on the authority and interests of Tana Toraja as a whole. All 30 lembang heads sat on the self-governing council, Kombongan Ada'. To make Tana Toraja practically governable, ten lembang heads (initially seven) formed in the Tongkonan Ada' and expected to settle many of the policy matters. Although all lembang heads had equal rights to be elected as a member of the Tongkonan Ada', in practice social stratification and descent predominated (Adatstaatrecht Loewoe 1947:47). The chairman and four members of the Tongkonan Ada' were responsible for executing daily matters and lived in Makale, the seat of self-government. These five members had to justify themselves to the whole council, which in turn had to justify its actions to the 30 members of the Kombongan Ada'. Nevertheless, accountability remained largely ceremonial, and real power belonged to the five Tongkonan Ada' members in Makale.

The Dutch were very much aware of the need to find a synthesis between a modern administration and the traditional form of government. Only a leadership rooted in adat yielded enough power and prestige to govern the division without massive internal political shocks. Nevertheless, in the four years that the self-governance of Tana Toraja existed, a satisfying synthesis between modern government organization and the

39 'Ada' 'carries the dual meaning of 'headman who settles small disputes' and 'traditional council' (Bigalke 1981:363). 


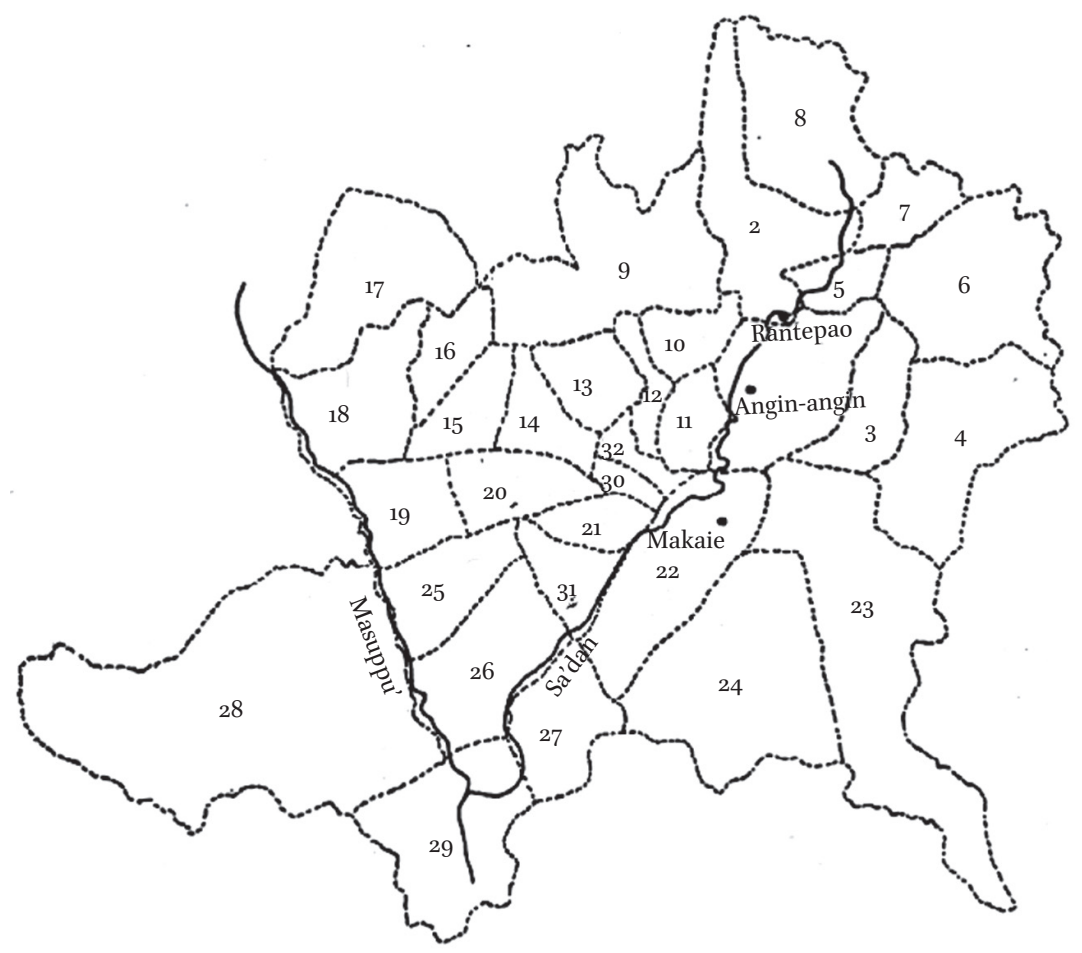

The districts (lembang) of Tana Toraja in 1940:
1. Kesu'
9. Pangala'
17. Pali
25. Mappa'
2. Tikala
10. Dende'
18. Ratte
26. Buakayu'
3. Buntao'
11. Madandan
19. Balepe'
27. Rano
4. Rantebua'
12. Piongan
20. Malimbong
28. Simbuang
5. Tondon
13. Kurra'
21. Talion
29. Bau
6. Nanggala
14. Ulusalu
22. Ma'kale
30. Banga
7. Balusu
15. Seseng
23. Sangalla'
31. Palesan
8. Sa'dan
16. Bittuang
24. Mengkendek
32. Tapparan

Map 4.2. The division of Tana Toraja into 32 districts in 1940.

Source: G.R. Seinstra, 'Memorie van overgave betreffende de onderafdeelingen Makale en Rantepao van den aftredenden Controleur bij het Binnenlandsch Bestuur. Bestuursperiode 18 juli 1935-1 januari 1940', 1939, in: Nationaal Archief, Den Haag, Ministerie van Koloniën: Memories van Overgave, 1852-1962, nummer toegang 2.10.39, inventarisnummer 1164.

traditional form of government was still not achieved, and disputes between Makale and Rantepao continued. Bigalke (1981:362) noted that 'Tana Toraja's unification under a zelf-bestuur [self-government] contained a good measure of illusion. Even as the cause which had united 
them ceremoniously triumphed, the old north-south rivalry between Makale and Rantepao protruded'. The structural monopolization of the two key administrative positions (chairman and chief civil servant) by headmen from Makale appeared to be unbearable for the Rantepao headmen, and they consequently demanded separation from Tana Toraja. Although this claim was rejected by the Resident of South Sulawesi, the Tongkonan Ada' was temporarily dissolved, and by the end of the Dutch era in the highlands, localistic tendencies were still influencing the Torajan political domain (Bigalke 1981: 366).

\section{Transformation of the Torajan Political System: The Feudal Authority Replaced}

In Tana Toraja, the struggle between federalism and unitarism was settled in favour of the latter by the end of April $195^{\circ}$ (Van Lijf 1951). Soon afterwards, a phase with rapid shifts started in the political and social worlds. For the fourth time since the Dutch intervention, local governance changed, this time to the disadvantage of traditional adat leaders. Tana Toraja again lost its political autonomy to Luwu, and it became largely isolated from the rest of the Indonesian Republic due to regional warfare. In this section, I now proceed to describe the transformation of the political system of Tana Toraja that took place under the Old Order regime of President Sukarno (1950-1965).

Since the proclamation of Indonesian independence in 1945, leading Indonesian politicians had been striving for two objectives: to assume power from the Dutch government; and to replace the feudal authorityfor the greater part maintained by the colonial regime-by new government systems based on western democratic understandings. ${ }^{40}$ Whereas the first objective had already been accomplished throughout the Indonesian archipelago by $1948,{ }^{41}$ the second objective seemed much more difficult to realize. The self-government of Tana Toraja-made up of adat leaders-seized even more power after the Dutch withdrew in 1947. However, support for adat leadership started to decline at the end of the 1940s. The general interest in political issues rose after children of the educated Torajan elites, who lived in Makassar, started to infuse Torajan

40 A. Ruibing, 'Concept van een beknopte algemene analyse politieke situatie Landschap Tanah Toradja', 1948, p. 1, in: Nationaal Archief, Den Haag, Losse Aanwinsten Indische Bestuursambtenaren, 1913-1979, nummer toegang 2.22.09, inventarisnummer 10, stuk 19.

41 With the exception of New Guinea (Irian Jaya). 
intellectuals with republican propaganda. ${ }^{42}$ Subsequently, Torajan individuals and groups established political associations and parties that reflected their aspirations.

After Indonesian independence (27 December 1949), the Tongkonan Ada' administration initially continued governing Tana Toraja under the new name of Dewan Pemerintahan Sendiri, or Self-Governing Council (Bigalke 1981:381). However, the council, which was dominated by the old elite, was disbanded a few months later on orders from a battalion of East Javanese troops of Tentara Republik Indonesia (TNI) that arrived in Makale in March 1950 (Bigalke 1981: 384). In line with the instructions of the new governor of South Sulawesi, pro-Republican leaders of local political parties and of society at large formed a local government that consisted of a council called Kommittee Nasional Indonesia (KNI) and a district head (kepala daerah). Bigalke noted that 'the day of the politikus (politician) has arrived...' and the tide turned to the benefit of the 'collage of parties and political groups' that had formed coalitions since February 1950.43 The 21 positions in the KNI were shared among Christian, Muslim and secular parties plus a few Torajan adat leaders who strongly favoured a unitary state. The traditional elites had been largely banned from the political domain and 'the spirit of reform was turned against the district and village heads who represented Jaman Belanda (the Dutch Era).... To minimize the problem of finding suitable replacements for the traditional elite, the KNI reduced the number of districts from 32 to 15 and consolidated the number of kampung from 410 to 132' (Bigalke 1981:387). In the same year, Tana Toraja once again lost its autonomy to Luwu and became the daerah pemerintah Negeri of Makale/Rantepao within the territory of Luwu (Daerah Swapraja) (Pakan 1977:29; Legge 1961:70).

Besides the radical transformation of the Torajan political world, independence marked a return to local warfare in the highlands that lasted until 1965. During this period, the people of Sa'dan Toraja were subjected to violent attacks from fundamentalist Muslim guerrilla troops from the Darul Islam (DI/TII) who were attempting to establish an Islamic state

42 A. Ruibing, 'Concept van een beknopte algemene analyse politieke situatie Landschap Tanah Toradja', 1948, p. 1, in: Nationaal Archief, Den Haag, Losse Aanwinsten Indische Bestuursambtenaren, 1913-1979, nummer toegang 2.22.09, inventarisnummer 10, stuk 22.

43 Bigalke 1981:383-5. The political coalitions that were established in Tana Toraja between February and April 1950 can be roughly divided into three groups: The Christian Party Parkindo with a strong preference for a unitary state; the Muslim parties PSII and Masyumi; and the secularist parties, of which the socialistically-inclined People's Sovereignty Party (PKR) was the most prominent (Bigalke 1981:383). 
(Morrell 2001:4). The real and perceived threat of Islamization induced many Torajans to defensively convert to Christianity. As membership of the Christian church was closely intertwined with that of the Indonesian Christian Party (Parkindo), it soon became the largest party in Tana Toraja (Crystal 1974:137). Parkindo generally represented the Torajan middleclass (educated Christians of the to makaka caste within the nobility). Dissatisfaction among lower-class peasants about the failure to realize land reforms, as promised by the Independence government, led to local acts of violence against the local traditional elites, pushing the latter even further to the margins of politics. The confiscation of thousands of parcels of land in Tana Toraja in the thirty years prior to 1906 had never been resolved by the Dutch. Instead, they had maintained the status quo 'in the interests of practicality and political stability' (Bigalke 1981:396). Especially in the southern part of Tana Toraja, people now started to reclaim the land from which their families had been evicted. "The claims of this wide layer of lower- and middle- class peasants became gradually organized within the Barizan Tani Indonesia, the ('Peasant Front'), associated with the Indonesian Communist Party' (Donzelli 2002/2003:68). Donzelli had found a police report in the provincial archive taking note of the fact that 'around the end of 1953 and the beginning of 1954 several groups of peasants started occupying and working their landowners' sawah (irrigated ricefields) in Palipu' and Marinding' (Donzelli 2002-2003:70). According to oral sources, the Indonesian Communist Party (PKI) promised the people of Palipu' that the expropriated land would be returned to the original owners or their descendants. Subsequently, during the 1950s, about 8 o percent of Palipu's inhabitants became members of the PKI. The descendants of puang Randanan had been threatened with being killed by the revolting peasants and sought protection by joining the Darul Islam rebellion (Donzelli 2002-2003:71).

Coupled with political ambitions and an emergent Torajan identity, this agitation led to strong Torajan rejection of political domination by Luwu. In Luwu, the nobility seemed to be torn between those who supported the Darul Islam rebellion and those against it, leaving a political vacuum between the opposing groups (Roth 2004). The resulting power gap was gradually filled by Javanese troops from the national army (in Luwu to establish and expand central control) as well as by Christian Torajans, who started to fill positions in Luwu's regional administrative apparatus due to their educational advantage over their Islamic lowland neighbours. By taking strategic administrative positions and maintaining good relations with representatives of the Luwu nobility 
'Toraja leaders had become important actors in the political arena of lowland Luwu' (Roth 2004:171). Supported by the majority of government administrative agencies, political parties and social organizations in Luwu, Torajan leaders officially proposed administrative independence from Luwu to the central government in 1953. In addition, the formation of a 'Greater Toraja' again started to play a role in regional politics.

Regional movements for greater political autonomy from the central government, which has started in Makassar in March 1957 (and known as Permesta), led to intensified violence in the region after Permesta troops joined with the guerrilla army of Darul Islam. ${ }^{44}$ According to several respondents, it was in this period that Palipu' came under the control of Andi Sose, the leader of the Darul Islam movement. A dozen tongkonan were burned down, and tens of villagers were sold as slaves to the lowland Bugis. It seems that attacks by Andi Sose in the northern region were less severe. In the midst of the turmoil that spread throughout Sulawesi, Tana Toraja was finally granted political autonomy in August 1957. It was administratively separated from Luwu, and both regions became regencies (Daerah Swatantra) within the province of Sulawesi. ${ }^{45}$ In 1959, Tana Toraja was formally established as an administrative unit referred to as kabupaten (district) or Daerah Istimewa (special region) (Liang Gie 1993:139). The new government of Tana Toraja was under the effective control of the Protestant party Parkindo that had obtained 15 out of the 20 seats on the Regional People's Representative Council (DPRD) (Crystal 1974:141). Parkindo managed to retain its monopoly on political control in Tana Toraja until the national elections of 1971. Although political independence was achieved, in their struggle for autonomy:

Torajan leaders took little time to think through the future consequences and see the possible dizadvantages. They headed for a district with a name that reflected their Christian-Toraja identity. It was only later that many leading politicians realized that there were serious dizadvantages to autonomy as well, that something had also been lost. For those envisioning the creation of Toraja Raya, separation from Luwu was considered as an important first step in that direction. Yet, separation was in fact moving away from the very definition of the 'Toraja' basis of the Toraja Raya ideal since part of the population of highland Luwu identified socio-culturally with Tana Toraja rather than with lowland Luwu. (Roth 2004:172.)

44 For a more detailed description about Darul Islam and Permesta in South Sulawesi, see Barbara Harvey 1974, 1977.

45 The separation of Tana Toraja from Luwu was prescribed in the emergency law (Undang-undang Darurat), Nr 3/1957, TLN 1138 (Liang Gie 1993:48). 
Due to internal mistrust, power struggles and conflicts, the ideal of Toraja Raya was never realized.

In the late 1950s and early 1960s, Java-based young intellectuals from Tana Toraja and Luwu developed the concept of 'Lutat' ${ }^{\prime} 6$ - a separate province that consisted of at least the administrative districts of Luwu and Tana Toraja (Roth 2002, 2003, 2004).

The plans showed both similarities and differences with earlier political lobbying for Toraja Raya. Lutat was characterized by the same political objective of breaking loose from Bugis-Makassarese South Sulawesi and becoming a province. There was the same awareness of the mutually supportive and complementary resources of Luwu (land) and Tana Toraja (people), of the common socio-cultural and historical ties, and the artificiality of existing administrative boundaries. However, the Jakarta-based group belonged to a younger generation than those who had propagated Toraja Raya, and this group did not like the latter's flavour of colonial missionary politics and Toraja expansionism. (Roth 2003:88.)

Lobbying for this idea in the national political arena was supported by members of the political elites in Luwu and Tana Toraja, leading to the support of President Sukarno by 1963. 'However, like Toraja Raya, Lutat did not materialize because of the fierce resistance from the political elite of lowland South Sulawesi who objected to the plans for separating Luwu and Tana Toraja from the province of South Sulawesi (Roth 2004:177).

In retrospect, the political scene in Tana Toraja seemed to have completely changed in just over a decade. The call for a new administrative unit called 'Greater Toraja' was eventually realized on a much smaller scale in the form of Tana Toraja (Ramstedt 2004:192). The Sukarno regime 'solved' the problem of integrating the traditional government structure into a modern administration by simply ignoring it. Sukarno's desire for a nationwide modernization of government, without any form of traditional authority, apparently bore fruit. A number of districts and kampung were merged, resulting in a reduction in the number of districts by more than half, and the reduction of kampung to one third of its previous number. Leadership of these newly-formed territories was predestined by young educated nationalists. Politically, the New Order government introduced a multi-party system from which the traditional adat leaders were excluded. The increasing popularity of the Parkindo party and the mass conversions to Protestantism challenged the power of the traditional

46 'Lutat' is the abbreviation for Luwu and Tator. 'Tator' is the short name for Tana Toraja. 
nobility of the Sa'dan-Toraja (Ramstedt 2004:199). After the strategic political elimination of traditional adat leaders at the start of the Dutch colonial administration, this was the second time in Tana Toraja's history that adat leaders were pushed aside. 'It was now the educated Protestants from the lesser ranks of Toraja society who were setting the trend for where society would have to go, i.e. embracing both modernity and Protestantism ... as a "modern" religion' (Ramstedt 2004:199).

\section{Decentralization and Local Autonomy: The Comeback of Traditional adat Leaders}

In 1965 , the rebellion in South Sulawesi was finally brought to an end by West Javanese troops and the region was at peace again. In the same year, the coup led by President Suharto heralded the era of the 'New Order'regime which was marked by a steady assumption of political power by the military at the expense of traditional political parties. In Tana Toraja, the first phase of the New Order government (1965-1979) saw a far-reaching administrative reorganization. In reality, the New Order government only proceeded along the lines already laid down with the decentralization and local autonomy laws of 1948 and 1957. In the context of this changing political climate, the Torajan nobility, who had never lost their taste for political power, sensed an opening to reassume authority over the regency. With this goal in mind, the nobles started to organize themselves under the flag of the non-religious political party Ikatan Pendukung Kemerdekaan Indonesia (IPKI) which was closely affiliated with the army (Crystal 1974:141).

The Desa Gaya Baru (New Style Village) elections of 1968-1969 provided the first opportunity for Torajan adat leaders to make a comeback to the political scene from which they had been absent for almost two decades. With the introduction of the New Style Villages in South Sulawesi, the Suharto regime had intended to reorganize the village structure and reinvent direct elections of village chiefs (Liang Gie 1967; Ardiwilaga 1970). In essence, the objective of the New Style Villages was to stimulate modernization and democratization from the inside out. ${ }^{47}$ Further, an aim was to stimulate the freedom of village governments and encourage cooperation with other villages and regencies (inter-regional cooperation). The actual execution of the New Style Villages decree of 1965 (Surat Keputusan $450 / x i i / 1965$ ) was fully delegated to the administrations of the individual

47 Based on Law 22/1948 that prescribed far-reaching village autonomy. 
regencies (Crystal 1971:126; Donzelli 2002-2003:30). Locally, the policy was implemented in 1967 after the government of Tana Toraja issued a local decree (Surat Keputusan 152/sp/1967) for the administrative reorganization of the regency (Donzelli 2002/2003:30). Subsequently, local boundaries of Tana Toraja were again redefined, and its 15 districts and 113 kampung were reduced in 9 districts (kecamatan) and 65 New Style Villages called lembang. ${ }^{48}$ Palipu' was integrated as a kampung within lembang Kandora, ${ }^{49}$ and Kondo' within lembang Tondon. Although the elections for the 65 newly-established lembang leaders were formally carried out without declared party affiliations, IPKI-backed individuals managed to win most of the 65 elections. "The lembang elections of 1968-69 had clearly proven that members of the old noble caste could [still] command the loyalty of traditionalist villagers in an open contest for local level political leadership (Crystal 1974:144-5)."

A 1970 Presidential Instruction (Inpres No. 6/1970) that made the participation of all civil servants in the new Golkar party compulsory enabled the nobility to completely bring down the Parkindo hegemony during the national elections of 1971. Golkar enlisted the support of all 'antiCommunist' factions of society (Ramstedt 2004:199). All lembang heads, except one, participated in Golkar and, using the same political forces as the lembang elections, they led Golkar to an overwhelming victory. ${ }^{50}$ Besides removing Parkindo as the controlling power, the majority of the seats in the new legislative (DPRD) and executive bodies (BPH) of Tana Toraja were now filled by the old elites as representatives of the government organ, Golkar. ${ }^{51}$

In a way, the political climate of the 1970s showed many similarities to the early Dutch administration. On a regency level, the nobility assumed political control over Tana Toraja, but it had to comply with the wishes of the central government. Again, the lowest level of the government structure, the lembang, remained largely beyond the reach of the Indonesian

\footnotetext{
48 After Tana Toraja obtained its autonomous status in 1957, the number of kampung was reduced from 132 to 113 under the command of its first regent, Mr. Lakitta (Sandarupa 1996).

49 Lembang Kandora consisted of the kampung of Tengan, Kalimbua' and Palipu'.

50 In Tana Toraja, 83.4 per cent of all votes went to Golkar (Crystal 1974:144). In total ten parties were involved in the regency elections.

51 The Legislative body DPRD (Dewan Perwakilan Rakyat Daerah) was a council consisting of 30 representatives from the regency. The BPH (Badan Pemerintahan Harian) was composed of five members who ran daily affairs. The head of the regency was appointed by the Indonesian government and usually held a high rank in the army (Nooy-Palm 1975:59).
} 
central government on account of its autonomous position. Although many traditional adat leaders might have returned to the centre of the political scene, and with a great amount of political autonomy to rule, the New Style Villages did not really coincide with the pre-colonial system and boundaries, as was also the case during the colonial period.

\section{Centralization and Standardization: adat Depoliticized}

In the 1970s, the central government started to strengthen its power over local communities and standardize regional variations in local government. This resulted in the introduction of a new law on Village Government in 1979. This law forced regional governments to transform the structure of village governments into an idealized Javanese model of the village. By standardizing village government structures throughout Indonesia, those government forms that were grounded in local traditions were completely ignored. In reality, the New Order regime feared regional and ethnic separatism and consequently were aiming to depoliticize adat, by reframing it as culture. ${ }^{52}$ Since modern government systems were first introduced to Tana Toraja, the system radically changed for the sixth time. The centralization politics of the New Order Government spanned almost two decades, until President Suharto was replaced and the recent era of reformation and decentralization followed, to which I shall turn shortly.

The so-called 'New Order Village' or desa, as formulated in Law No 5 of 1979, was implemented in Tana Toraja in 1985 and the only recently established New Style Villages were again fragmented into a larger number of desas (see Table 4.1 for a historical overview of the changes in administrative divisions in Tana Toraja over the past century). The administrative boundaries of lembang Kandora, in which Palipu' was integrated did not change, but, it was renamed as desa Tengan. The term lembang in front of Ma'tallo' was simply changed into desa, and this did not have any further consequences for Kondo'. The power of the central and regional governments over the newly formed desa was based on intimate personal relations and on patronage. 'Whether lured by privileged access to funds or forced by intimidation, virtually all leaders, local notables and people with prestige and authority inevitably became state clients. 'Village leaders, the loyal state clients, became the axis around which governance, politics and funds circulated. So while heads were powerless in relation to higher

52 Culture was mainly expressed in houses, artefacts and clothing, thus excluding social structures and traditional laws and regulations based on tradition. 
Table 4.1. Historical overview of the changes in administrative divisions in Tana Toraja.

\begin{tabular}{|c|c|c|c|c|}
\hline \multirow[t]{2}{*}{ Period } & \multicolumn{4}{|c|}{ Administrative Units } \\
\hline & Large & & & Small \\
\hline $\begin{array}{l}\text { Before } 1906 \\
\text { 'Traditional' } \\
\text { socio-political } \\
\text { organizations }\end{array}$ & $\begin{array}{l}\text { Tallu } \\
\text { Lembangna }\end{array}$ & Lembang & $\begin{array}{l}\text { Bua'/ } \\
\text { penanian }\end{array}$ & Tondok \\
\hline $\begin{array}{l}\text { 1906-1926 } \\
\text { Dutch } \\
\text { administration }\end{array}$ & $\begin{array}{l}2 \text { subdivisions: } \\
\text { Makale and } \\
\text { Rantepao }\end{array}$ & $\begin{array}{l}31 \\
\text { districts }\end{array}$ & $\begin{array}{l}4 \text { sub- } \\
\text { districts } \\
28 \\
\text { complexes }\end{array}$ & $\begin{array}{l}400 \\
\text { kampung }\end{array}$ \\
\hline $\begin{array}{l}\text { 1927-1945 } \\
\text { Dutch/ } \\
\text { Japanese } \\
\text { administration }\end{array}$ & $\begin{array}{l}1 \text { subdivision } \\
\text { Makale- } \\
\text { Rantepao }\end{array}$ & 32 districts & $\begin{array}{l}17 \\
\text { complexes }\end{array}$ & $\begin{array}{l}400 \\
\text { kampung }\end{array}$ \\
\hline $\begin{array}{l}1946-195^{\circ} \\
\text { Dutch control }\end{array}$ & $\begin{array}{l}\text { Self-governing } \\
\text { Division } \\
\text { Tanah Toraja }\end{array}$ & $\begin{array}{l}32 \\
\text { lembang }\end{array}$ & & $\begin{array}{l}410 \\
\text { kampung }\end{array}$ \\
\hline $\begin{array}{l}1950-1965 \\
\text { Sukarno's Old } \\
\text { Order }\end{array}$ & $\begin{array}{l}\text { Daerah } \\
\text { pemerintah } \\
\text { Negeri Makale/ } \\
\text { Rantepao; } \\
\text { Daerah } \\
\text { Swatantra } \\
\text { (1957); and } \\
\text { Kabupaten } \\
\text { Tana Toraja } \\
\text { (1959) }\end{array}$ & $\begin{array}{l}15 \\
\text { lembang }\end{array}$ & & $\begin{array}{l}132 \\
\text { kampung; } \\
113 \\
\text { kampung } \\
(1957)\end{array}$ \\
\hline $\begin{array}{l}\text { 1965-1979 } \\
\text { Suharto's New } \\
\text { Order (Phase } 1 \text { ) }\end{array}$ & $\begin{array}{l}\text { Kabupaten } \\
\text { Tana Toraja }\end{array}$ & $\begin{array}{l}9 \\
\text { kecamatan }\end{array}$ & $\begin{array}{l}65 \\
\text { New Style } \\
\text { Villages }\end{array}$ & \\
\hline $\begin{array}{l}\text { 1979-1998 } \\
\text { Suharto's New } \\
\text { Order (Phase 2) }\end{array}$ & $\begin{array}{l}\text { Kabupaten } \\
\text { Tana Toraja }\end{array}$ & $\begin{array}{l}15 \\
\text { kecamatan }\end{array}$ & $\begin{array}{l}290 \text { desa/ } \\
\text { kelurahan }\end{array}$ & $\begin{array}{l}\text { 9oo dusun/ } \\
\text { lingkungan }\end{array}$ \\
\hline
\end{tabular}


authorities, they were, in exchange for their subordination and loyalty, endowed with almost unlimited powers within their community.' (Antlöv 2003:196.)

The former lembang committees, which were still grounded on local traditions, were replaced by Village Consultative Assemblies (Lembaga Musyawarah Desa, or LMD). The desa head automatically became the chair of the LMD and, in consultation with the sub-district government and the Village Guidance Army Officer, he also appointed the other members of the Assembly. Since any mechanism for the local population to hold the desa head accountable was lacking, he possessed considerable power within his own territory. However, the desa head was at least not 'imported' from outside, and remained part of the community (kinship group) he ruled. Thus, despite his allocated power, he still had to move within the constraints of cultural and social acceptance.

The administrative and social levels that formerly existed below the lembang level were abolished and replaced by the dusun (hamlet). Both Palipu' and Kondo' became dusuns under the new administrative system. The head of a dusun was appointed by the desa head but was relatively powerless and just an arm of higher-ranked administrators. In the New Order administration, units differed with respect to whether an area was considered 'urban' or 'rural' (Donzelli 2002/2003:30). Tana Toraja regency (kabupaten) was considered a predominantly rural area but was endowed with a mixed system. The basic administrative unit throughout the area was therefore the desa, but in and around the two towns of Makale and Rantepao the urban administrative units 'kelurahan' and 'lingkungan' were applied, corresponding to the rural desa and dusun respectively. In contrast to the desa head, who was selected through regular elections, the head of a kelurahan (a lurah) was appointed by the district head (ibid. 7). While, the total number of administrative units initially differed only slightly from the 9 districts and 65 lembang established under the New Style Villages system, by the introduction of the lembang in 2002, Tana Toraja had 15 districts, 290 desa and kelurahan and over 900 dusun and lingkungan.

During the New Order Period, the borders of penanians changed several times, and the borongna was basically replaced by the idea of Rukun Tetangga (RT). The Suharto government introduced this administrative unit, which is comparable to the saroan in the sense that it was launched as a neighbourhood association in which gotong royong was promoted. However, the territory of an $R T$ is usually artificially marked, cross-cutting borongna and saroan boundaries. 


\section{Conclusions}

In the last century, the Torajan world was regularly changing under external pressures and interference. The area was colonized by the Dutch, then occupied by the Japanese, and subsequently came under the control of various successive Indonesian governments. Within the Torajan social space, a continuous struggle took place between various people and parties over the ultimate stakes - power and prestige. Although the stakes in the power game, and the arena in which it is played, have remained largely the same, the rules of the game have been frequently changed by external governments. After a long process of wielding and yielding involving various players, Tana Toraja has become the way it is.

Early Torajan social space consisted of a number of social groupings, or kinship networks, that differed in size and in constellation. The smallest single entity was a set of siblings that formed a kindred centre which was based on ancestral houses or tongkonan. These tongkonan anchored people to a particular place in contemporary Tana Toraja. In many respects, pre-colonial Torajan society fits the 'house society' image postulated by Lévi-Strauss. ${ }^{53}$ Although the early kinship groupings in the highlands were linked to particular places by ancestral houses, they were not territorially based. Early Sa'dan people did not think of their place in terms of a bounded territory until the Dutch arrived. The Dutch laid the foundations for contemporary Tana Toraja by delineating the highlands into districts, sub-districts and villages. What has followed has been a long cycle of power politics with successive power and policy changes on national and regional levels. The history of the transformation of local territories, government systems, and the Torajan adat leaders' involvement in them, has been the struggle to come to terms with the ever-changing political realities in a rapidly changing world. Although Torajan traditional government systems initially continued to exist alongside the political administrations of the Dutch and Indonesian states, they were increasingly deconstructed and eliminated under the various regimes, most notably under the government of President Suharto.

The cycles of governmental and territorial changes in Tana Toraja went hand-in-hand with the traditional elite's participation in the political field. The history of Tana Toraja is coloured by struggles between elites from the

53 Lévi-Strauss 1983:174. See Chapters 5 and 6 for more detailed information on the tongkonan as the basis of house societies. 
noble class concerning authority in the social, political, economic and cultural domains. Most notably, these fights were between the nobilities from the northern and southern regions of Tana Toraja, but they have also taken place between various adat community leaders and even puang families alike. With the introduction of a 'political field' by the Dutch colonial regime, politics became the central instrument to enhance or at least maintain, power over certain people and available resources. Although the nature of the elites changed due to the introduction of education, money, Christianity and migration, the old nobility and their descendents continued to return to the political stage in Tana Toraja. Members of the old noble caste have been banned from the political scene on no less than three occasions (the inception of Dutch rule, from 1950-1968, and from the late 1970s through 1998) but have several times also proven that they can command the loyalty of the Torajan population in open contests for local-level political leadership. Here it should be added that some rich middle-class people have entered this arena, supported by the central government, or assisted by the ability to buy votes or through increasing their social status, but the majority of the people born in the middle and lower strata of society are still excluded from participation in Tana Toraja's politics.

To conclude, neither the administrative unit of Tana Toraja, nor the total population of the Sa'dan-valley, are self-evident frameworks. What constitutes the place of Tana Toraja is rather the outcome of social and political processes that run more-or-less in parallel with each other. It is constructed as both an administrative unit and as a socially constructed place. In Massey's words, the particular mix of social relations that form part of what defines the uniqueness of Tana Toraja, as a place, are by no means all included within the physical boundaries of the area itself. It includes relationships that stretch beyond. Hence the Torajan social space is much larger than the place itself. What is considered to be Tana Toraja, as a living place or homeland, differs by group and even by individual, and it does not necessarily conform to particular administrative boundaries, or to local kinship groupings or to organizations. 